\title{
Perancangan Sistem Informasi Penjualan Timbangan Berbasis Web Pada PT. Altraman
}

\author{
${ }^{1)} Y$. Rainhard Siregar \\ UNIKA Santo Thomas Medan, JI. Setiabudi No. 479 F, Sumatera Utara, Indonesia \\ http:// www.ust.ac.id, Email : siregarrainhard@gmail.com \\ ${ }^{2}$ Sorang Pakpahan \\ UNIKA Santo Thomas Medan, JI. Setiabudi No. 479 F, Sumatera Utara, Indonesia \\ http:// www.ust.ac.id, Email : sorangpakpahan2701@gmail.com
}

\begin{abstract}
The development of the internet world is highly expected for the present because more and more private companies, agencies take part in enlarging these developments in carrying out their business activities. So to support this, PT. Altraman is a company engaged in the sale of digital scales that offer quality products at competitive prices and provide convenience for stake holders. In this final project, an information system for the sale of web-based scales was designed at PT. Altraman which aims to process the data of stock procurement, sales and shipping and to market the scales products well through the built website media, so that it can facilitate the sale of products, and can increase sales volume. With the existence of this system it is expected that it will be easier, both for companies and customers in carrying out the sales and purchase process.
\end{abstract}

Keywords: Scales, Stock, Sales, Shipping, Web, Information Systems

\section{PENDAHULUAN}

Proses yang berjalan di PT.Altraman ini masih terbilang sederhana, karena pada penjualan dan pemasaran masih menggunakan sales dan juga tidak memiliki website penjualan khusus timbangan yang memuat seluruh info timbangan. Pada perusahaan ini konsumen harus mendatangi perusahaan langsung atau menelfon untuk memesan dan melihat model timbangan. Sedangkan cara melakukan pemesanan nya dengan membuat Purchasing Order terlebih dahulu atau uang muka, lalu kemudian dilakukan pengiriman barang.

Adapun layanan purna jual yang ada di perusahaan ini ialah dengan cara memberikan garansi selama 1 (satu) Tahun,dan jika dalam proses pengiriman barang rusak maka akan dilakukan service dan pergantian barang. Pada perusahan ini juga menyediakan sperpart untuk timbangan yang perlu diganti sperpart nya dan layanan itu masuk dalam garansi.

Oleh karena itu dirancang suatu sistem penjualan secara online dengan menggunakan media web atau internet untuk dapat meminimalkan waktu proses penjualan dengan tujuan dapat meningkatkan volume penjualan sehingga pendapatan perusahaan dapat meningkat ${ }^{[9]}$.

\section{METODE PENELITIAN}

Dalam penelitian yang penulis lakukan, penulis menggunakan beberapa metode pengumpulan data, antara lain:

1. Metode Observasi

Suatu metode pengumpulan data dengan cara melakukan pengamatan secara langsung terhadap obyek yang akan diteliti serta pendataan secara cermat dan diplomatik

2. Metode Interview

Pengumpulan data dengan cara mengadakan wawancara langsung dengan pemilik dan karyawan PT.Altraman. Hal ini penulis mengajukan pertanyaan-pertanyaan yang sesuai dengan masalah yang akan dipecahkan dan semua hal mengenai PT.Altraman.

3. Metode Pustaka

Pengumpulan data dengan cara mengumpulkan literatur, jurnal, paper, dan bacaan-bacaan yang ada kaitannya dengan judul penelitian.

4. Metode Dokumentasi

Suatu metode untuk mengumpulkan data dengan cara mengambil dari dokumendokumen pihak yang bersangkutan dalam hal ini PT.Altraman.

\subsection{Perancangan Sistem}

\subsubsection{Diagram Konteks}

Perancangan Sistem Informasi Penjualan Timbangan Berbasis Web Pada PT. Altraman.

Oleh : ${ }^{1)}$ Y. Rainhard Siregar, ${ }^{2)}$ Sorang Pakpahan 


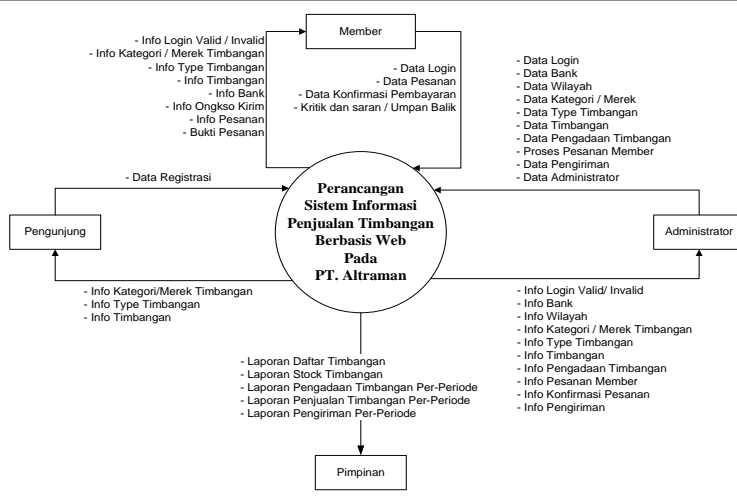

Gambar 1 Diagram Konteks Perancangan
Sistem Informasi Penjualan Timbangan

Berbasis Web

Perancangan Sistem

Penjualan Timbangan Berbasis Web Pada

Altraman yang disajikan dalam konteks diatas masih terdapat proses-proses pencatatan data, seperti penginputan data, proses pengadaan, pemesanan, konfirmasi, pengiriman dan pembuatan laporan ${ }^{[7]}$. Hubungan proses tersebut disajikan dalam diagram arus data level 0 , yang diberi penomoran proses. Hubungan antara proses tersebut dapat dilihat pada Gambar 2.

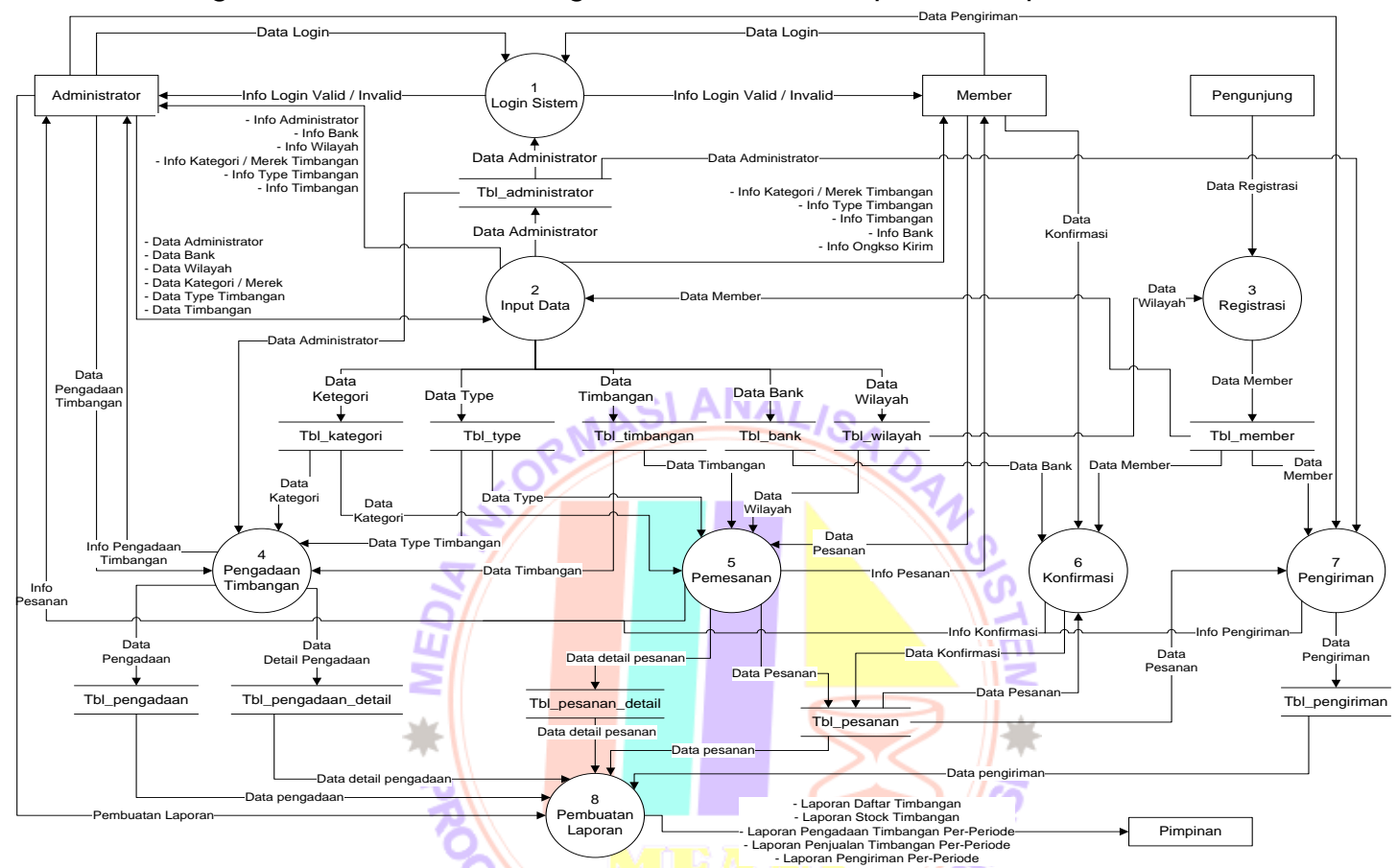

Gambar 2 Diagram Arus Data Level 0 (Nol)

\subsection{Rancangan Antar Muka dan Rancangan Input}

Dari hasil rancangan output dan database yang diperoleh diatas maka dapat diketahui kebutuhan rancangan antarmuka dan rancangan input yang diperlukan oleh sistem ${ }^{[5]}$. Adapun rancangan antarmuka dan rancangan input yang akan dirancang pada sistem yang akan dibangun adalah:

\section{Halaman Utama}

Menu utama atau beranda merupakan tampilan utama pada saat sistem atau website dijalankan, dimana pada menu utama banyak terdapat pilihan link yang berguna untuk berpindah dari satu halaman ke halaman lainnya. Bentuk menu utama dapat dilihat pada Gambar 3.

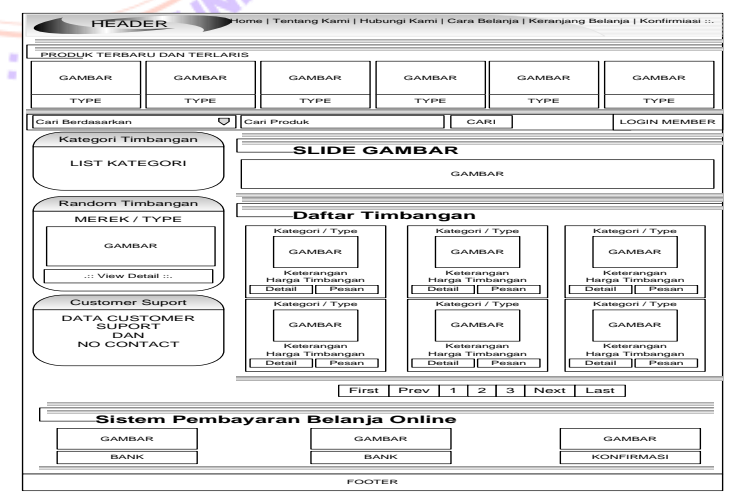

Gambar 3 Rancangan Halaman Utama

2. Halaman Administrator

Halaman administrator berfungsi untuk melakukan pengolahan data administrator, mulai dari penginputan, pengeditan dan penghapusan data administrator. Bentuk 
halaman administrator dapat dilihat pada Gambar 4.

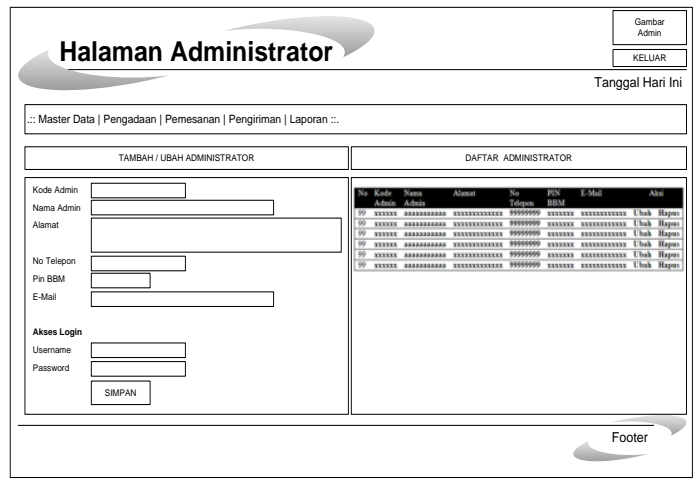

Gambar 4 Rancangan Sistem Halaman Administrator

\section{HASIL DAN PEMBAHASAN}

Halaman umum adalah halaman yang dapat diakses oleh seluruh pengunjung yang membuka website yang sudah dibangun. Adapun halaman-halaman yang dapat diakses setiap pengunjung adalah sebagai berikut.

\section{Halaman Utama Atau Beranda}

Pada saat website dibuka maka pengunjung akan masuk ke halaman utama, dimana pada halaman utama terdapat informasi tentang PT. Altraman dan daftar timbangan yang dijual. Halaman utama pada website yang dibangun dapat dilihat seperti pada Gambar 5

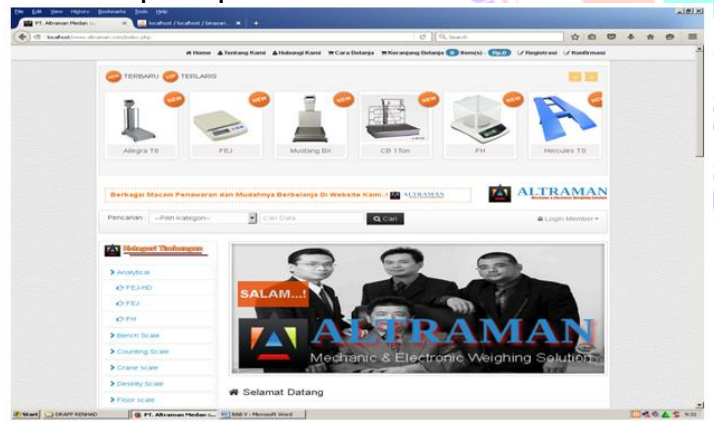

Gambar 5 Halaman Utama Atau Beranda

\section{Halaman Profile}

Halaman profile merupakan salah satu halaman yang dapat diakses oleh setiap pengunjung website PT. Altraman. Halaman profile akan menyajikan informasi mengenai sejarah berdiri, visi dan misi serta struktur organisasi dari PT. Altraman. Halaman profile dapat dilihat seperti pada Gambar 6

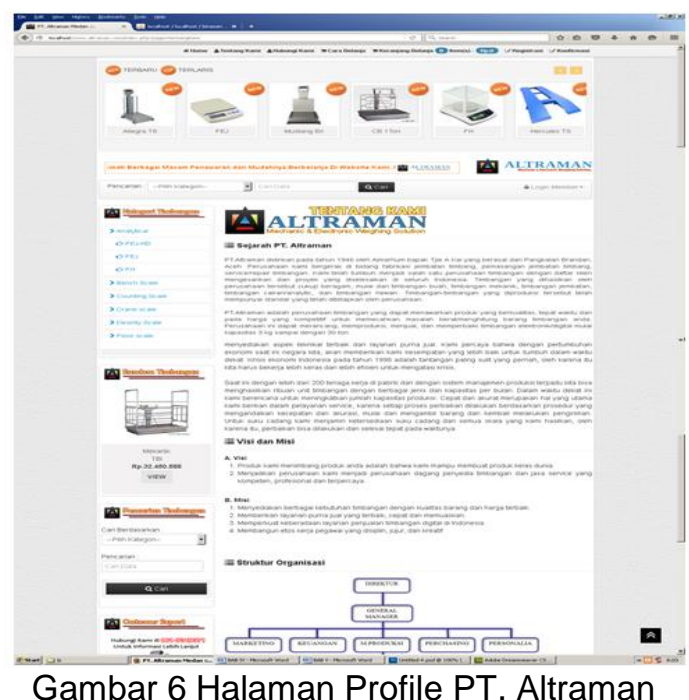

\section{Halaman Login Administrator}

Halaman login administrator merupakan salah satu halaman yang dapat diakses oleh seorang administrator pada PT. Altraman. Halaman login administrator berfungsi untuk masuk ke halaman administrator. Halaman login administrator dapat dilihat seperti pada Gambar 7.

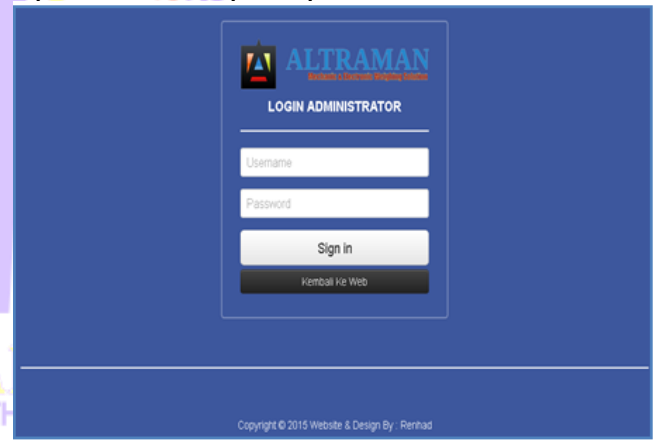

Gambar 7 Halaman Login Administrator

\section{Halaman Utama Administrator}

Halaman utama administrator merupakan salah satu halaman yang dapat diakses oleh seorang administrator pada PT. Altraman. Halaman utama administrator berfungsi untuk menambah, mengubah dan menghapus data. Halaman utama administrator dapat dilihat seperti pada Gambar 8

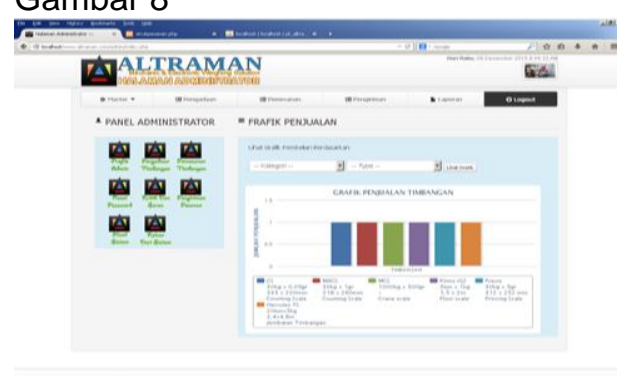


Gambar 8 Halaman Utama Administrator

\section{KESIMPULAN}

Dari proses analisis, perancangan dan implementasi yang dilakukan pada bab-bab sebelumnya, maka dapat diambil kesimpulan sebagai berikut:

1. Dengan adanya Sistem Informasi Penjualan Timbangan ini, maka proses penjualan produk mulai dari proses registrasi, pemesanan produk, pengiriman produk dan pembuatan laporan dapat dilakukan dengan baik dan efisien.

2. Sistem yang dibangun dapat menampilkan secara online tentang layanan dan produk PT. Altraman secara luas.

3. Proses pemesanan dan pembelian dapat dilakukan dengan cepat, dimana member dapat langsung melakukan pemesanan dan pembelian sesuai dengan jenis timbangan yang di inginkan tanpa harus datang langsung ke kantor PT. Altraman.

\section{DAFTAR PUSTAKA}

1. Jogiyanto, 1989, Analisis dan Desain, Andi Offset, Yogyakarta.

2. Kadir Abdul, 2014, Pengenalan Sistem Edisi Revisi, Penerbit Andi Offset, Yogyakarta.

3. Nugroho Adi, 2006, e-Commerce, Penerbit Informatika, Bandung.

4. Peranginangin Kasiman, 2006, Aplikasi Web dengan PHP dan MySQL, Penerbit Andi, Yogyakarta.

5. Prasetyo Eko, 2008, Pemrograman Web PHP \& MySQL untuk Sistem Informasi Perpustakaan, Graha IImu, Yogyakarta.

6. Raharjo Budi, 2011, Belajar Pemrograman Web, Penerbit Informatika, Bandung.

7. Sutabri Tata, 2012, Analisis Sistem Informasi, Penerbit Andi Offset, Yogyakarta.

8. Sutanta Edhy, 2004, Sistem Basis Data, Penerbit Graha Ilmu, Yogyakarta

9. Sutedjo Budi, 2009, Perencanaan \& Pembangunan Sistem Informasi, Penerbit Andi, Yogyakarta.

10. Utdirartatmo Firrar, 2002, Mengelola Database Server MySQL di Linux dan Windows, Andi Offset, Yogyakarta.

11. Jatmiko, N., Syahrial, H., \& Minsni, H. (2010). Analisa Dan Perancangan Sistem Informasi Dalam Layanan Penjualan Berbasis Web Pada Mall Puri Indah, Yogyakarta.

12. http://www.journal.uii.ac.id/index.php/Snati/art icle/download/1852/1627 (05 Juni 2015)
13. Viktor Nicolas,2013,Perancangan Sistem Informasi Penjualan Produk Berbasis WEB,Universitas Widyatama Bandung.

14. ]http://repository.widyatama.ac.id/xmlui/bitstre am/handle/123456789/2193/1104020.

pdf?sequence $=1$ (03 Juni 2015) 